\title{
スワンプマンにさよならする
}

前田高 弘

\begin{abstract}
Swampman is a philosophical creature invented to show that some form of externalism in the philosophy of mind is wrong. Many philosophers seem to take it for granted that swampman's coming into being is conceivable, and therefore metaphysically possible. In this paper I question that very assumption while admitting the significance of the inference from conceivability to possibility. For evolutionarily and naturalistically motivated externalists, I suggest, the best way of responding to the swampman-argument is to deny the metaphysical possibility of the existence of swampman. I show why that is metaphysically impossible from a naturalistic viewpoint.
\end{abstract}

\section{1. スワンプマンとは何であり，なぜそれが問題であるのか}

次のような状況を思い描いて見よう。あなたが帰宅の途上沼の近くに差し かかったとき，稲妻があなたを襲い，あなたの体は分子レべルまで粉々に破 壊されると同時に, 別の稲妻が沼に沈んだ大木に命中し, 舞い上がった無数 の粒子が結合しあってあなたの物理的に完全なレプリカが誕生する。あなた のレプリカは何事もなかったかのようにあなたの自宅に向かい, 帰宅すると あなたが書こうとしていた論文に取り掛かる ${ }^{1}$. 注意されたいのは，このレプ リカと双子地球タイプの思考実験におけるレプリカとの違いである. 前者は 進化史や個体史などの歴史を全く欠くのに対し，後者はそれ独自の歴史をも つとされている，ここでは，前者をスワンプマン，後者をドッペルゲンガー と呼ぶことによって区別することにしよう。さらに注意されたいのは，スワ ンプマンは全くの偶然の産物であるという意味で適切な歴史を欠くというこ とである.だから，あなたのレプリカ（クローンではない）が人主的に作ら 
れたとしても，それはスワンプマンではないし，それはあなたを介して間接 的に歴史をもつとも言えよう ${ }^{2}$.

心の哲学における標準的な外在主義は歴史を重視するが，スワンプマンの 例はそのような外在主義に挑戦するものである. 志向性を生物学的機能の観 点から捉え, 生物学的機能を進化史によって決定されるものとして捉える外 在主義にとって，その挑戦はとりわけ脅威となる ${ }^{3}$. その上さらに，感覚質 （qualia）を志向化することによってそれをも進化史的に捉える外在主義に とっては，その挑戦は極めて深刻である．というのも，スワンプマンが通常 の意味での信念内容を欠くとは言えても，単に進化史をもたないというだけ でそれが感覚質を全く欠くというのは明らかに直観に反するからだ.

私は基本的に上述の種頢の外在主義が正しいと考える者であり，スワンプ マンを重大な挑戦として受け止めているが, 多くの外在主義者のスワンプマ ンに対する応答は十分に満足のいくものではないように思われる. それらの 応答は，スワンプマンのような存在者を一旦受け入れたうえで，それが生物 学的機能をもつと言えるかなどを論じているが, スワンプマンとあなたが物 理的な構成において異なる所が全くない限り，たとえ前者が生物学的機能を 欠くとされても，それは「生物学的機能」の解积の違いに過ぎないように見 える.

スワンプマンに対する最良の応答は，その存在自体を拒否することである と私は考える．スワンプマンの出現は想像可能であり, 故にそれは形而上学 的に可能であるという前提を多くの哲学者が当然のように受け入れてしまっ ているが，私はまさにその前提を拒否する．ただし，想像可能性から形而上 学的可能性を導く推論そのものを否定するのではない. 次節でその種の推論 そのものは擁護されるべきだとしたうえで,物理主義的自然主義の観点から， スワンプマンの出現が形而上学的に可能ではないと考えるべき理由を述べた いと思う ${ }^{5}$.

\section{2. 形而上学的可能性への手掛かりとしての想渙可能性}

様々な認識的探究において我々は，現実に成り立っている事実だけでなく， 現実には成り立っていない事態や法則の可能性をも視野に入れることによっ て事物の本質に迫ろうとする，とりわけ，世界の一般的構造や原理などに関 心をもつ哲学者や科学者にとって, そのような形而上学的可能性を考慮する ことは彼らの知的営みの不可欠の部分を成す。しかし，何かが形而上学的に 可能であるという判断がいかに可能であるのかはそれ自体哲学的な検討を要 する問題である.だが，その判断能力についてどのような説明が与えられる 
にせよ, 我々が実際にその能力を行使する際に何を行っているか, また何を その判断の根拠と見なしているかは既に自明であるように思われる. 即ち 我々は, 問題の事物が成立ないし存在する状況を想像しようと試み，その試 みがうまくいく場合にその事物が形而上学的に可能であると判断する。その ことは, 事物の形而上学的身分を論じる典型的な哲学的議論がしばしば想像 可能性に訴えているのを見ても確かであると思われる。しかし, 想像可能性 が形而上学的可能性への手掛かりとしてどの程度信頼できるのかもまた哲学 的な問題であり，しばしば否定的な評価を受けてきたのも事実である.ここ では，哲学的方法としての想像可能性の限定的な擁護をしたいと思う。

以下の引用において, ヒュームは想像可能性と形而上学的可能性との間に かなり密接なつながりがあると主張しているように見える.

心が明瞭に想像することは何であれ可能的存在の観念を含む，あるい は言い換えると, 我々が思い描く何物も絶対的に不可能ではないことは 形而上学において確立された格率である ${ }^{6}$.

注意すべき点が二つある。一つは，何であれ想像できることは可能である という主張は明らかに強すぎるということ，擁護されるべきは，誤ることも あるが有力な手掛かりとしての想像可能性である。もう一つは, 上の引用に おいて実は二つの異なる主張がなされていること7. 即ち, 前者は, 想像され る事物は可能なもの亡して表象される, といった表象に関する主張であるの に対し, 後者は, 想像される事物と可能な事物とのいわば外的な関係につい て述べている. そして, 興味深いのは前者の方である. 私が想像可能性を擁 護するのは，あくまでそれが形而上学的可能性の観念を含む限りにおいてで ある。

即ち, 何かが想像可能であるとは, それが形而上学的可能性の見かけを 伴っているということである。このように想像可能性を規定することは，あ る種の認識的循環を犯しているように見えるかもしれない. 例えば Tidman は，想像可能性の攡護者の基本的な主張を，(1） P は想像可能である， もし Pが想像可能であれば $\mathrm{P}$ は可能である, という二つの前提から, Pは可 能であるという結論を導くものとしたうえで, それらの前提がその結論を暗 に前提することによってしか主張できなければその推論は循環に陥るとして いる ${ }^{8}$. そして彼は, 想像可能性が有意義であるためには, 問題の命題が可能 であるか否かとは独立にそれを規定できなければならないと要求している. 彼によれば,想像可能性を主張する議論のほとんどがその要求に背いている. 
だが, 上述の想像可能性の規定は, 問題の命題が可能であることを前提し ているわけではない（可能であるように思われることは可能であることとは 異なる)，このような想像可能性がいかに有意義であり得るかを理解するに は, 知覚とのアナロジーに注目するとよい ${ }^{9}$.一般に何かを知覚することは, その知覚される何かが存在するように思われること（あるいは何かがしかじ かであるという見かけを伴うこと）である．しかし，だからといって，何か を知覚することは，その何かが存在することを論理的に帰結するということ にはならない.(「知覚する」を達成動詞として捉えるならば話は別である.同 様に, 「想像できる」も達成動詞として解积し得るが, ここでは知覚も想像も その認識的手段としての有効性が問題になっているから, 達成は前提されて いない. ) 我々が知覚に期待することはせいぜい, それが概して正常に機能す ることである.そして, その期待は裏切られないが故に, 何かを知覚するこ とによって，その何かが存在すると判断することがうまくいくのである．ま た，それ故に，知覚を疑うべき正当な理由がない限り，その知覚を信用する ことが合理的となる. 同様のことが想像可能性に対しても当てはまるように 思われる.

しかし, どの程度当てはまるのか.一つの晒念は, 想像可能性の信頼性の 程度が知覚の場合と比べてそれほど明らかではないことである. 知覚につい ては，そのメカニズムやそれが正常に機能するための条件などが比較的よく 知られているが, 我々の様相的判断力が何に由来するのかについては同様に よく解明されているとは言えない. だが, 想像可能性を批判する議論の多く は, 問題のある解釈によって想像可能性を捉えており, 適切に解釈された想 像可能性が信頼に足るものではないことを説得的に示した議論は存在しない ように思われる ${ }^{10}$.

また, 哲学的方法という観点から見た場合, 何が形而上学的に可能である かを判断する手掛かりとして，想像可能性に訴えることは不可避であるよう に思われる。それは，究極的には知覚に訴えることなしにこの世界の事物を 認識することが不可能であるのと䫑比的である. 想像可能性に訴えることを 禁じることは, 形而上学的可能性について論じることを禁じることに等しい だろう。もちろん, 想像可能性を無批判に肯定することは避けなければなら ない. 哲学は互いの直観を単にぶつけ合うだけのものではないから, 合理的 な実りある論争を実現するために, 想像可能性に訴える議論はとりわけ批判 的に検討されるべきだろう. だが，想像可能性そのものに罪はない．基本的 に, 想像可能性に基づく議論については，その議論が間違っていることが明 白でない限り，挙証責任はその議論に反対する側にあると言えよう。 


\section{3. スワンプマンは形而上学的に可能か？}

それは明白に不可能であるとは言えないようである．スワンプマンの例を 使って外在主義を批判する側はもとより，その批判に答える側も，それが可 能であることを受け入れたうえでそれが生物学的ないし心的特性をもつか否 かを問題にしているからである.そして，それが形而上学的に可能であるこ との主な根拠は，それが少なくとも想像可能であるように見えることであろ う.したがって, 前節の終わりに示した原則により, 挙証責任はスワンプマ ンの可能性を否定する側にある。この節で私はその責任を果たしたい.

しかしその前に, 以下の議論の基本的な戦略を示しておこう。想像可能性 はしばしば不適切な仕方で適用され，そのために形而上学的可能性の判断が 誤ってなされることがありうる。 そのような場合は，その問題の事物につい て，どのような意味でそれが想像可能であるのかを厳密に問い直すことによ り，それが想像可能であるように見えたのは錯覚であったことが判明するで あろう. 私の診断では, スワンプマンを巡る議論のほとんどがその錯覚に基 づいている．それ故，スワンプマンが出現するような世界がいかに我々の現 実世界から掛け離れているかを示すことにより，スワンプマンの形而上学的 可能性を疑わしくさせ，結果的にスワンプマンが想像可能ではなくなるよう にすること, これが私の戦略である.ここでは, 想像可能性は形而上学的可 能性に従うであろう。

スワンプマンが想像可能であるように一見思われるのは何故であろうか. 有力な要因として考えられるのは, それが出現する様子を映像的に思い浮か べることができることである. 即ち, 稲妻が沼の大木を粉々に分解し, 舞い 上がった無数の細かい粒子や破片が互いに結合しあって,ついには人間の形 となる様子を視覚的にイメージすることができるように思われる.もちろん， 個々の細胞のレベルまでを覆うディテールによってイメージすることなどで きないが, ある種の抽象化や木目の粗さは心的イメージの本質的特性である から, そのことは必ずしも問題ではない. 問題は, 心的イメージはそれ自体 では何が想像可能であるかを一義的に决定しないというところにある. 例え ば, 天に向かって投げられた石が空中に停止したまま落ちてこないという状 況をイメージしてみよう。そのときあなたはこの現実世界の物理法則が成り 立たない状況を想像しているのだろうか, それとも, 目には見えないが重力 に逆らう何らかの力がその石に作用している状況を想像しているのだろうか. いずれであるにせよ，あなたがそこで何を想像しているのかは視覚的なイ メージだけでは決まらないはずである. 
ここでの重要なポイントの一つは次のことである. 即ち, この現実世界の 事物との関連で何が形而上学的に可能であるかを判断する場合は, 問題に なっている可能世界がこの世界の物理的存在者のタイプや自然法則を共有し ているか否かを考慮に入れなければならない"11.そしてさらに私は，その問 題となる可能世界はこの世界の物理的存在者のタイプと自然法則を共有して いるものでなければならない，と主張したい，スワンプマンも結局この世界 の事物との関連でその可能性が問われている以上, 存在者のタイプや自然法 則がこの世界と大きく異なる可能世界を持ち出しても意味がないのである. だが, この点については少し敷延する必要がある.

まず予想される反論は, 問題の可能世界がこの世界の物理的存在者のタイ プを共有しなければならないことは認めても，自然法則まで共有しなければ ならないことにはならない, というものである。この反論は, 物理的存在者 が同じでも自然法則は異なり得ると前提しているが, 私はそのようには考え ない. 私の考えでは, 自然法則は物理的存在者とは独立に存在するようなも のではなく, 究極的には素粒子のような基礎的なレベルの物理的存在者 ${ }^{12}$ が それ自体としてもつディスポジショナルな性質に由来するものである.また， そう考える方が物理主義的自然主義に適っているように私には思える.

だがこれは結局, 自然法則に関する哲学的見解の相違であり，この場で决 着のつく問題ではない. ただ, スワンプマンの問題に関しては, 仮に物理的 存在者のタイプを共有しつつ自然法則が異なる可能世界を認めたとしても， そのような可能世界がこの世界の事物に関する哲学的テーゼに対してどれだ けのインパクトをもつのか私には疑わしい. 自然法則の異なる可能世界にお いてスワンプマンが可能であることは，現実世界と自然法則を同じくする可 能世界においてスワンプマンが可能であることを意味しない.そして，この 問題にとって興味深いのは後者の可能性であろう.というのも, 後者の意味 で可能でない限り，それは実質的に可能でないことに等しいからである。も とよりここでは物理主義的自然主義が前提されており, 私が想定する論争相 手もその前提を共有する者である.そして物理主義的自然主義者の信条の一 つは, 我々自身を含むこの世界の事物を自然科学が描く世界像と整合するよ うに捉えなければならないということである。つまり, 物理主義的自然主義 者である我々にとって興味のある可能性はあくまで, この世界について自然 科学が述べる法則が許容する限りのものであるはずなのだ。もちろんそのよ うな自然主義を前提していても，自然法則の異なる可能世界について考える ことが無意味であるわけではない．だが，問題になっている事柄がまさに自 然法則に関わってくる場合は, 自然法則を同じくする可能世界を問題にすべ 
きであり，スワンプマンはまさにそのような場合なのである.

問題となる可能世界はこの現実世界と物理的存在者のタイプや自然法則を 共有していなければならないことを確認したうえで次に私がなすべきことは， そのような世界ではスワンプマンの出現が不可能であることを示すことであ る.その最初のステップとして私は，スワンプマンの出現がいかにありそう にないことか，ということを強調したい。これに対して，この世界で生命が 出現したこともある意味で奇跡に近いのではないかという反論が予想される. この反論に答えることによって, スワンプマンが現実世界の生命のあり方か らいかに掛け離れた存在者であるかを際立たせたいと思う。

我々人間を含めてこの世には合目的的で複雑かつ精巧な器官を備えた生物 が多く存在する。このような物理的存在者が全くの偶然によって生じたとす れば，それは途方もない奇跡である。そしてまさにその奇跡が現実に起こっ たのだとすれば，それはスワンプマンの出現と実質的に同じであり，我々は スワンプマンの子孫であることになろう。だが，そのような奇跡は起こるは ずがなく，そのような物理的存在者がどのようにして存在するに至ったのか についての何らかの歴史・因果的な説明があるはずだ，と考えるのが我々に とって自然な態度であることは重視されるべきである．例えば，あなたが神 の存在を信じていなくても，人間が神によって創造されたとする仮説と，人 間は全くの偶然によって生じたとする仮説のうちのどちらかを選ぶとすれば， 前者を選ぶ方が合理的であろう。少なくとも，後者を選ぶ方がより合理的 であるとは言えない ${ }^{13}$. ペイリーが論じたように, 道端に石が落ちていて も，その石は単なる偶然の結果としてそこに存在すると言えるが，時計の ような特定の目的に寄与する精妙なメカニズムをもつものが落ちていれば， それは元々誰かがその目的を意図して作ったのだと考えるべきである．だ からといって創造説が正しいことにはならないが，ダーウィンの進化論が 登場するまでは，人間のような存在者のまさにその存在がその説の有力な 証拠と見なされていたことは忘れるべきではない．そして，ダーウィン流 の進化論の一つの眼目は, 創造主のような別の次元の奇跡を持ち出す事な く, 合目的的かつ精妙な生命体の存在を自然主義的に納得のいく仕方で説 明できることにある。

ダーウィニズムの説明力を理解するには, 錠前のアナロジーが役に立つ ${ }^{14}$. あなたの目の前にたくさんのダイヤルの付いた組み合わせ式の錠前があり， あなたはその暗証番号を知らないとする. 適当にダイヤルをいじくることに よって錠前が開く確率は極めて小さい. だがもし，ダイヤルをいじくる度に 暗証番号に一致する部分があればその部分が自動的に固定されて動かなくな 
るようにしたとすれば，あなたがそのことを知らずランダムに試行を繰り返 すとしても，試行を絽り返すうちに暗証番号にたどり着く確率は極めて大き くなる.つまり，たった一回の試行で暗証番号と完全に一致することは奇跡 に近いが，部分的に一致することはよくある．ただ，部分的に一致してもそ の部分が固定されなければ, 試行を何回繰り返しても確率の低さは変わらな い. だが，その部分が固定されるようにすると確率が飛躍的に高くなる。こ れをダーウィニズムに置き換えれば，その部分的な一致は「適応的に有利な 突然変異」に対応し，それが固定されるメカニズムは「遺伝と自然淘汰のメ カニズム」に相当するだろう。それらはダーウィン的な進化のプロセスに とって必要不可欠のものであるが, 錠前のアナロジーは, それらが累積的な 効果によって確率的にありそうなものから確率的にありそうでないものをい かに生み出し得るかを示している。

ここで注意すべきは，適応的に有利な突然変異はランダムに発生するが, それが遺伝と自然淘汰のメカニズムによって累積的な効果を及ぼすことに より，合目的的で精妙な生命体を生み出すプロセスそのものはランダムでは ないということである。そして, 適応的に有利な形質は, 自身のコピーを増 やす能力において競争関係にある他の遺伝的個体より少し上回ることに寄与 するものであればよいから，そのような突然変異がランダムに発生するのを 期待することは十分に合理的である。いずれにせよ，そのような変異の発生 がある種の幸運であるとしても，一回の突然変異によってアメーバから人間 が生まれる奇跡に比べれば，その幸運の程度は比較にならないほど慎ましい ものである.

もし我々が上述のダーウィニズムのポイントについて無知であれば，スワ ンプマンの奇跡は現に人間のような生命体が存在することの奇跡とそれほど 大差はない，という反論はそれなりに有効ではあろう. だがダーウィニズム の観点から見ると, その反論の誤りは「大差はない」というところにある. ス ワンプマンが出現することと, ダーウィン的進化のプロセスを経て人間が出 現するに至ることとの間には天と地ほどの隔たりがある.

しかし，この世界に我々のような生命体が存在すること自体がある意味で 奇跡に近いという主張は部分的に正しいかもしれない.というのも, ダー ウィニズムが機能するためには遺伝のメカニズムが存在しなければならず， この惑星ではそのメカニズムが DNA や RNAによって担われていることは よく知られているが, それ自体が非常に精妙にできており, 全くの偶然に よって突然生じたとは考えられない代物であるからだ。自己複製する分子 (自己複製子) としては DNA はかなり洗練されており, それ自体がより原始 
的な自己複製子から段階を踏んで進化してきたものと考えられる.だがいず れにせよ，自己複製子が必要である。初期の地球の大気の成分とされるもの を混ぜ合わせて放電にさらすとアミノ酸ができることは実験的に確かめられ ており，今日の標準的学説は生命の起源をそのような有機物に求めているが， その学説でも自己複製子がいわば失われた環となっている. 即ち, 自己複製 子さえあれば，ダーウィン的プロセスはそれほどの奇跡に訴えずに人間さえ も創造し得るが, 生命の起源のまさに最初の段階においてある程度の奇跡に 訴えざるを得ないように見えるのである.

一口に奇跡と言ってもその程度にはかなりの幅がある．ここで奇跡とは， 自然法則を超越するような事象ではなく，問題となる可能世界における自然 的事物の一般的な振る舞い方 (即ち自然法則) に照らしてあまり起こりそう にない幸運や偶然の一致などを指す。つまり，その発生が自然法則的に不可 能ではないが極めて稀であるような事象として, どの程度までの奇跡が許容 されるかは世界に相対的であると言える.したが?て, 生命の起源の最初の 自己複製子の出現が奇跡であるとすると，それは我々の世界が属するタイプ の世界においで゙の程度の奇跡であるのかが問題である．極限のケースは， その世界において生命が出現するのはせいぜい一つの惑星においてのみであ る場合である。これは我々の世界について言えば, 生命が出現したのは地球 だけということになる．もしそうであるならば，生命が出現するのに適した 惑星の数分の一の確率程度の奇跡をこの世界は許容すると言える. Dawkins の試算に従えば，その確率は一兆の一億倍分の一である ${ }^{15}$.これは途方もな い奇跡ではある ${ }^{16}$. だが私にとって必要な論点は, その奇跡と比べてさえ，ス ワンプマンの奇跡がはるかに途方もないものだということである. Dawkins が言うように，それだけの奇跡が許容されるなら DNA が自然に現れるには 足りるだろうが, ダーウィン的プロセスなしでスワンプマンのように複雑で 精巧な存在者を出現させるにはほど遠い. 仮にスワンプマンの出現する確率 を $\mathrm{n}$ 分の 1 として数值化できるとすれば, $\mathrm{n}$ は惑星の数はおろか宇宙にある 原子の数をはるかに凌ぐほどの数になろう．このように数值化して見ると， 一口に途方もない奇跡と言ってもその程度にはかなりの幅があり得ることが わかるだろう.

さて，スワンプマンの出現がいかにありそうにないことかを論じたうえで 次に私がなすべきことは，それが単にありそうにないだけでなく形而上学的 に不可能であると考えるべき理由を示すことである．そのためにまず，物理 的 (自然的) 可能性, 形而上学的可能性, 論理的可能性の区別について考え る必要がある。ある事象の生起が物理法則に反しなければそれは物理的に可 
能であり，またその生起の想定自体が論理的矛盾を含んでいなければそれは 論理的に可能であると取り敢えず言えるだろう. 我々の世界の自然法則とは 全く異なる法則を想像することができるから, 物理的可能性は論理的可能性 の一部分であるにすぎない，問題は，それらの可能性に対する形而上学的可 能性の位置付けである. 私の印象では, 形而上学的可能性と論理的可能性を 同一視するか，あるいはほとんど区別しない哲学者が多い. だが物理主義的 自然主義の観点を取るとき, そのような同一視が妥当であるかどうかは決し て自明ではないことに注意すべきである.

空に向けて投げられた石が空中に停止したまま落ちてこないことは論理的 に可能であるかを考えてみよう。それが物理的に可能であれば，物理的可能 性は論理的可能性を含意するから，明らかにそれは論理的に可能である.だ が，それが物理的に可能ではない場合（つまり，重力に拮抗する目に見えな い別の物理的な力の作用を受けることなしにその石が空中に浮かんでいる場 合)，それが論理的に可能であるかはそれほど明らかではない.その場合にそ れが論理的に可能であるとする主な論拠は，この世界の物理法則が成り立た ない状況を論理的に排除することはできないということであろう。しかし， この論拠が意味を成すためには, 問題の石やそれを取り巻く環境がこの世界 の基礎的な物理的存在者と同じタイプの存在者によって構成され，かつそれ らがこの世界の物理法則に従わないものとしてその状況は捉えられなければ ならない，確かにそれは，純粋に論理的な理由によって排除できるようには 見えない，だが，既に触れたように，自然法則に関するある形而上学的見解 をとれば，その論拠は意味を成さない，もちろん，それが意味を成すのを許 容する形而上学的見解もあるだろう。いずれにせよポイントは, 自然法則に 関する論理的というより形而上学的な判断にかかっている.

仮にスワンプマンの出現がこの世界の自然法則に反するとした場合，それ でもそれは論理的には可能であるという主張が理解可能であるのは, 基礎的 な物理的存在者のタイプを共有しつつ自然法則が異なり得るとする形而上学 的見解にそれが則っている限りにおいてである.そのような見解をとる限り， 形而上学的可能性は論理的可能性にはるかに近いと言えるだろう。だが，そ のような見解をとる立場は, 物理主義的自然主義のあり方に関して前に述べ た論拠によって排除される. またその論拠によって, 物理主義的自然主義者 である我々にとって有意義な形而上学的可能性の概念は,物理的 (自然的) 可 能性のそれにはるかに近いと言える ${ }^{17}$.

では，この世界の自然法則はスワンプマンの出現を許容するのだろうか. 前に私は, 合目的的で複雑かつ精巧な生命体がいかに存在するに至ったのか 
について，それが全くの偶然によって生じたのではなく，合理的な歴史・因 果的説明が存在すると考えるのが我々にとって自然であるという事実を重視 すべきだと述べた，我々人類が偶然によって突然生じたなどということが考 えられないとすれば，それは結局，スワンプマンのような存在は考えられな いということに等しい．その論点を補強する二つの論拠を挙げておきたい. 一つは，一見逆説的ではあるが，生命体がそれぞれ種に固有の進化史をもつ ことは，その生命体のもつ精妙さよりもむしろ不完全さによって示されてい るということである.これは, 自然淘汰が進化の行き先に詨して盲目であり， その都度の時代環境に適応した遺伝的変異のみが選択されることの必然的結 果であると考えられる ${ }^{18}$.もう一つは，偶然に生じたとすれば非常な偶然で あるように見えるものにはそれを説明する何らかの原因が存在する可能性が 高いということは，この世界の因果的構造に由来する基本的な事実であろう ということだ. 非常な偶然の見かけを解消するような因果的メカニズムを探 ろうとする我々の性向もその世界の因果的構造に根差していると考えられる. ただし，何が起こりそうでないかに関する我々の判断力は，我々が日常的に 用いる時空的尺度によって制約されていることに注意しなければならない． 特に我々は, 非常に大きなスケールや非常に小さなスケールでは想像力がう まく働かないことが多い. 生命の起源について最大限どの程度の奇跡が許容 されるかについて論じた際, その最大限度の奇跡がスワンプマンレベルの奇 跡とどれだけ遠く離れているかは，具体的に数值化して見ない限り分からな かったであろう。

私の診断では, スワンプマンの出現が形而上学的に可能であると主張する 論者も，スケールの規模の違いに由来する錯覚に陥っているのである ${ }^{19}$.も とより,彼らもそれが極めて起こりそうにないことは承知しているはずだが， その奇跡の程度がいかに杵外れのものであるかを十分には理解していないの だ.だが，一旦それを理解するならば，その形而上学的可能性の見かけは怪 しくなってくるのではないか.いずれにせよ，前に述べたように，視覚的イ メージのみによっては想像の内容は決まらず, どのような法則が成り立つも のとしてその世界を想像しているのかが問題である.そして，スワンプマン が形而上学的に可能であるか否かの判断は結局のところ, 我々の世界の自然 法則がその奇跡を許容すると考えられるか否かの問題に行き着く . 私として は，許容するとは考えられないことの論拠を示すことによって，取り敢えず は想像可能性に関する挙証責任を果たしたと考えたい。 


\section{4. 結び}

注意されたいのは, 私はスワンプマンがある種の生物学的機能や心的特性 （ないしそれに似た何か）をもつことを否定してはいないということだ ${ }^{20}$. ス ワンプマンが通常の照明の下で赤いリンゴを目の前にしたとき，彼はあなた が同様の条件下でもつ経験と同じ経験をもつという直観は, 内在主義という より，物理的スーパーヴィニエンスに基づく自然主義に由来するものである ように思われる. だが他方で, 心的特性を進化論的な観点によって捉えよう とする外在主義も同様の自然主義によって動機づけられており, 本稿は, こ の自然主義の内部における対立を調停する試みであると言える ${ }^{21}$ 。この試み によって，外在主義者たちがスワンプマンに悩まされなくなれば幸いである． だが，たとえそうならなくても，スワンプマンを自然法則に関する形而上学 的問題の中に位置づけることによって, 志向性や感覚質に関する哲学的議論 の場そのものからはスワンプマンに別れを告げることができれば私は満足で ある。そこではドッペルゲンガーだけで十分だろう ${ }^{22}$.

\section{注}

1.この例は Davidson に由来する.Cf. D. Davidson, 1987, “Knowing One’s Own Mind", rep. in Q. Cassam, ed., Self-Knowledge (Oxford U.P.1994), 46.

2. 特定の誰かのレプリカでなくても，それが人工的に（ないし創造論者の神に よって）作られたものである限り，それはスワンプマンではない.

3. Davidsonのように, 進化史ではなく, 単に個体史だけを要求するような外在 主義者にとってスワンプマンはそれほど脅威とはならないかというと，そうでも ないようだ. D. Brown, 1993, “Swampman of La Mancha”, Canadian Journal of Philosophy, 23: 327-47 を見よ.

4. 主な文献を私の目に触れた限りで挙げておく. R. G. Millikan, 1989, “In Defense of Proper Functions", Philosophy of Science, 56: 288-302. K. Neander, 1991, "Functions as Selected Effects: the Conceptual Analyst's Defense", Philosophy of Science, 58: 168-84. D. Papineau, Philosophical Naturalism (Blackwell,1993), 91ff. F. Dretske, Naturalizing the Mind (MIT Press, 1995), 141-51. M. Tye, Ten Problems of Consciousness (MIT Press, 1995), 153-55. W. A. deVries, 1996, "Experience and the Swamp Creature", Philosophical Studies, 82: 55-80. ただし, Millikan と Neander は心の哲学ではなく生物学の 哲学における問題として扱っている，また，Tyeはスワンプマンが感覚質を持つ ことを認めている点で DretskeやdeVriesらと異なるが，彼の立場は機能に関す る非歴史的見解にまつわる困難 (MillikanやNeanderを参照) に悩まされるよう 
に思われる.

5. したがって, 外在主義そのものよりも, スワンプマンの形而上学的可能性が本 稿の主題となる. スワンプマンの形而上学的可能性を容認した上での生物学的外 在主義の擁護は, 物理主義的自然主義の立場を取る限り, 不十分なものとならざ るを得ないというのが私の直観である。また, 生物学的機能は本質的に進化史に 依存するという外在主義の論点も, むしろスワンプマンのような存在が形而上学 的に不可能であることによって部分的に支持されるものであるように思われる. 生物学的機能に基づく外在主義そのものの是非については, スワンプマンによる 反論が回避されたとしても，さらなる議論を要するであろうが，ここでの課題は まず先にスワンプマンを葬り去ることである．

6. L. A. Selby-Bigge, ed., A Treatise of Human Nature (Oxford U. P. 1967), 32.

7. Cf. S. Yablo, 1993, “Is Conceivability a Guide to Possibility?", Philosophy and Phenomenological Research, 53: 1-42, 4.

8. P. Tidman,1994, "Conceivability as a Test for Possibility", American Philosophical Quarterly, 31: 297-309, 298.

9. 知覚とのアナロジーによる想像可能性の肯定的な評価は,Yablo, ibid. や Tye, ibid., 185-88にも見られる.

10. この点に関する詳細な議論については Yablo, ibid. を参照されたい. 想像可能 性に対する私の評価は彼に負うところが大きい。 なお, Tidmanは, 直観的に何 かが可能であると思われるときのその直観を「様相的直観」と呼び，これを想像 可能性と区別し, 様相的判断が依存するのは想像可能性ではなく様相的直観であ るとしている.だが，これは単に言葉の違いに過ぎないように思われる．私が想 像可能性と呼ぶものは様相的直観を含んでいる.

11. 物理的存在者のタイプを共有するとは, この現実世界の諸事物が基本的に物理 化学的な素材によって構成されている（あるいはそれ自体が物理化学的な実体で ある）のと同様に，その可能世界の諸事物が, 物理化学的という点で同じタイプ の素材 (ここで「物理化学的」は一種の固定指示詞である) によって構成されて いる，ということである，ただ，その可能世界の諸事物を構成する素材の種類が 現実世界のそれと完全に一致する必要はないかもしれないが, その世界が自然法 則的に現実世界と十分よく似ていると言える程度に一致する必要はある。また， 自然法則を共有するということについても，細部まで完全に一致する必要はない かもしれないが（例えば物理定数の值がそれぞれ少しずつずれていることが可能 かもしれない)，少なくとも保存則や対称性原理といった根本的な原則に関わる基 本的な法則については一致する必要がある.

12.ここで私の念頭にあるのは, レプトンやクォークなど, それ自体内部構造をも たないような粒子である. Cf. S. Mumford, 1998, “Laws of Nature Outlawed”, Dialectica, 52: 83-101.

13. この点について詳しくは, E. Sober, Philosophy of Biology (Oxford U. P. 
1993), ch. 2 を参照されたい.

14. Cf. Sober, ibid., 36ff.

15. R. Dawkins, The Blind Watchmaker (Norton, 1986), 146. [中嶋康裕その他 訳, 日高敏隆監修, 「ブラインド・ウォッチメイカー」(早川書房, 1993)，241]. ダーウィニズムや奇跡に関するこの辺りの考察はこの本に負うところが大きい.

16. ただし，これはあくまで最大限に見積もった場合の奇跡である．もしそれだけ の数の惑星が存在するなら，そのうちのいくつかの惑星において生命が誕生する ことはほぼ確実であるように私には思われる。 また, 立花隆,『サイエンス・ナウ』 (朝日文庫，1996），238-56によると，はるかにもっと小さな奇跡で済みそうな気 配がある.

17.このあたりの議論のポイントは,形而上学的可能性を論理的可能性から区別し, その概念を自然法則のタイプ（これが問題となる可能世界のタイプを決定する） によって限定されるものとして捉え直すことにある.スワンプマンの出現という 想定自体は論理的矛盾を含んでおらず，その意味でそれは少なくとも論理的に可 能であり，だからこそそれがいかにありそうにないことかについて諲ることが意 味を成すように思われる，だが，それがいかにありそうにないことか（言い換え ると，それが実現するにはどれくらい途方もない奇跡が要求されるのか）につい ての議論は，それが形而上学的に可能であるか否かの問題とは独立である. 少な くとも私は，スワンプマンの出現する可能性の確率的な低さについての議論を， スワンプマンの形而上学的不可能性の論証と混同する誤りを犯しているつもりは ない. しかし逆に, 確率についてどのような解釈を取るにせよ, その確率が（限 りなくゼロに近くても) ゼロではないということを, スワンプマンが形而上学的 に可能であることの端的な論証と見なすことも同様に誤りであると思う.そして， 物理主義的自然主義にとって有意義な形而上学的可能性の概念が，この現実世界 の物理的存在者と自然法則の性格によって限定されるものであるとすれば，スワ ンプマンが形而上学的に可能であるか否かの問題は結局，この世界の自然法則が スワンプマンレベルの奇跡を許容するような性格のものであるか否かの問題にな る, というのがこのあたりの箇所で私が言わんとすることである. ちなみに私は, 形而上学的可能性を物理的可能性と同一視しているわけではない. 自然法則の基 本的な性格が究極的に素粒子のような基礎的な物理的存在者の性格によって決ま るとしても, 注11で触れたように, コンティンジェントな部分を含むことも可能 かもしれない，もしそうであれば，己の世界において物理的に不可能でありなが ら，法則的に十分よく似た別の世界において物理的に可能であるような事象を含 むように形而上学的可能性を捉えるべきであろう.いずれにせよ, 形而上学的に 可能なことは，この世界において物理的に可能なことよりも多くのものを含む.

18.この点については, S. J. グールドの古典的エッセイ『パンダの親指」(櫻町翠 軘訳,ハヤカワ・ノンフィクション文庫, 1996）を参照.

さらに今一つここの論点を補強するように思われる生物学的事実として, 遺伝 暗号（コドン）とアミノ酸との対応関係には特別の必然性がないのに, 地球上の 
全ての生物種においてその対応関係が一致していることが挙げられる.このこと は, 地球上の生命が全て単一の起源から派生してきたことを示すものであると考 えられている。

19. あるいは, 形而上学的可能性を論理的可能性と単純に同一視しているかのどち らかである。

20. そもそも形而上学的に不可能なものについてそれがいかなる特性をもつかを問 題にする必要があるのか, とレフェリーの一人が指摘されたが，もちろんその必 要はないというのが私の答えである. だが, 形而上学的に不可能なものでも, 仮 にそれが可能だとした場合にどのようなことが言えるかを問うことは必ずしも無 意味ではないだろう。

21. Dretske, ibid.の反応と比較されたい.

22. 有意義な注文と助言を寄せてくださったレフェリーの方々に感謝します.

（大阪大学大学院） 